\title{
Kia whakatōmuri te haere whakamua: 'I walk backwards into the future with my eyes fixed on my past'
}

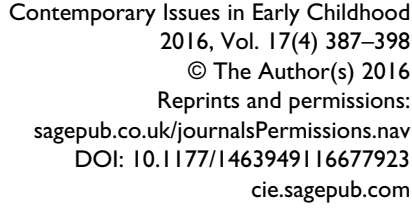

(9SAGE

\section{Lesley Rameka}

University of Waikato, New Zealand

\begin{abstract}
This whakataukī or 'proverb' speaks to Māori perspectives of time, where the past, the present and the future are viewed as intertwined, and life as a continuous cosmic process. Within this continuous cosmic movement, time has no restrictions - it is both past and present. The past is central to and shapes both present and future identity. From this perspective, the individual carries their past into the future. The strength of carrying one's past into the future is that ancestors are ever present, existing both within the spiritual realm and in the physical, alongside the living as well as within the living. This article explores Māori perspectives of the past and the models and inspiration they offer. In this way, it provides a critique of the practices in early childhood education, highlighting the importance of cultural concepts and practices, and discusses implications for both teaching and academic practice.
\end{abstract}

\section{Keywords}

Māori, early childhood, time, culturally responsive, pedagogy

\section{Introduction}

Kia whakatōmuri te haere whakamua.

I walk backwards into the future with my eyes fixed on my past.

This whakataukī or 'proverb' speaks to Māori perspectives of time, where the past, the present and the future are viewed as intertwined, and life as a continuous cosmic process. Within this cosmic movement, time has no restrictions - it is both past and present (Tse et al., 2005). Patterson (1992) argues that, from a western perspective, the past tends to be behind and one's goals and aspirations relate to the future, which is ahead. From a Māori perspective, the opposite is the case. The past and the present are knowable, and so are viewed as in the forefront of human consciousness, whereas the future cannot be seen and therefore is conceived of as 'behind' (Walker, 1996). Walker (1996: 14) explains that the individual is 'conceptualised as travelling backwards in time to the future, with the present unfolding in front as a continuum into the past'. This conceptualisation of time does not leave the past behind; rather one carries one's past into the future. The strength of 
carrying one's past into the future is that ancestors are ever present (Patterson, 1992; Walker, 1996), existing both within the spiritual realm and in the physical, alongside the living as well as within the living. Within this epistemological and ontological frame, ancestors who have passed on, while existing within the spiritual realm, still remain in the physical, alongside the living, and this is recognised in the way Māori conduct their lives (Ministry of Justice, 2001). '[T]he spirits of the dead or living are accepted as real phenomena whereas life is seen as a transitory process moving from body-to-body and generation-to-generation' (Tse et al., 2005: 183). Patterson (1992) explains that acknowledging and seeing ancestors in the physical environment is akin to acknowledging and seeing oneself. He explains that, as ancestors are present in the everyday world, it is just a matter of viewing the world as the world of ancestors. It relates to acknowledging and taking pride in ancestral heritage and recognising the contributions ancestors have made to tribal culture, etiquette and values.

This article explores ways in which ancestors are acknowledged in the environment and examines how Māori perspectives of the past can provide guides for early childhood education provision. It offers an analysis of time through engaging with notions of past, present and future as an experience of selected and connected cultural concepts of Te Ao Māori ('the Māori world'). While 'time' as a cultural concept is not specifically referenced in the article, it does indicate how time is something that is experienced in relation to cultural concepts such as wairuatanga ('spirituality') and tikanga ('customs'). In this way, it provides a critique of the practices in early childhood education, highlighting the importance of cultural concepts and practices, and discusses implications for both teaching and academic practice. The article will firstly discuss important cultural concepts related to the past, such as wairuatanga ('spirituality') and whakapapa ('genealogy'). Next, it will frame some of the ways in which the past is brought to the fore in Māori cultural practices and understandings, and the significance of these practices not only in terms of being Māori and Māori identities, but also as models of culturally responsive pedagogy in early childhood practice.

\section{Wairuatanga and whakapapa}

The concept of wairua is derived from Māori cosmology. The term literally means 'two waters' the spiritual and the physical. It is an expression of the relationship between the physical and the spiritual, and of the wholeness of life. Love (2004: 9) states that '[w] airuatanga may be understood as analogous to two streams merging as a flowing river, with associated ebbs, eddies and currents'. People - past, present and future - and their relationships with the environment and events can be thought of in terms of the flow of the wairua.

Barlow (1991) explains that the spirits of people come from the Rangi Tühāha a, the 12 dimensions of enlightenment in the company of the gods. This is where the spirits exist until they are required for the physical life of the person, and where the spirit returns after physical death. The physical and the spiritual potential of the person are joined at conception, becoming an individual entity endowed with spiritual qualities. The worlds are intimately connected with activities in the everyday material world coming under the influence of and interpenetrated by spiritual powers from the spiritual world (Marsden, 2003; Ministry of Justice, 2001; Reilly, 2004; Shirres, 1997). In this way, people are inherently connected with the universe, with the world of spiritual powers, the world of the gods. '[T]he cultural milieu [of Māori] is rooted both in the temporal world and the transcendent world, this brings a person into intimate relationship with the gods and his universe' (Marsden, 2003: 137).

Wairuatanga and whakapapa are intimately related. Whakapapa ('genealogy') is central to Māori concepts of identity - past, present and future. Whaka can be translated as 'to enable' or 'cause to happen', and papa refers to something broad and flat. Whakapapa relates to a process of placing in layers, so there are multiple layers and interpretations that form the basis of Māori values 
and beliefs (Cheung, 2008; Te Rito, 2007; Walker, 1993). Whakapapa is a continuous lifeline from those who existed before to those living today, encompassing everything that is passed from one generation to the next. Patterson (1992) emphasises the importance of whakapapa, explaining that it is one's whakapapa that makes one who one is, literally. Whakapapa, therefore, is fundamental to Māori understandings and is at the very core of what it means to be Māori (Barlow, 1991; Berryman, 2008; Cheung, 2008; Rangihau, 1977). It is 'firmly embedded in the Māori psyche' (Te Rito, 2007: 4).

Whakapapa connects the individual to the past, present and future: to Ranginui ('Sky Father') and Papatūānuku ('Earth Mother'); to whenua ('land'); whānau ('families'), hapu ('sub-tribe') and iwi ('tribe'); to moana ('lakes'), awa ('rivers'), maunga ('mountains') and waka ('ancestral canoes') (Mead, 2003; Ministry of Justice, 2001); and to the spiritual world and the universe (Te Rito, 2007). From a Māori perspective, people are not superior but related through whakapapa to all aspects of the environment, themselves imbued with spiritual elements. Māori are part of the environment, connected to everything in it; therefore it requires respect. Furthermore, at birth, the ancestors' umbilical cords were buried in the land and, on their death, their bodies were buried in the land. They were therefore conceptualised not just as inhabitants of the land, but as the land itself. Wolfgramm and Waetford (2009: 5) explain that these 'dynamic and intimate interrelationships between the spiritual, social and natural worlds and the indeterminacy of evolutionary processes in a Māori worldview are captured through creation stories which include layers of symbolism and metaphor'.

In Māori cosmology, the gods (ngā Atua) are the origin of species. For example, the offspring of Tāne, Tū, Tāwhiri, Tangaroa, Rōngo, Haumia (and some 70-odd others) eventually populated the universe with every diverse species known. Under this system, humans are related to both animate and inanimate objects, including animals, fish, plants and the physical environment (land, rocks, water, air and stars). Thus there is no separation between the physical and spiritual worlds; in the holistic Māori worldview they are continuous. (Cheung, 2008: 3)

Identity - past, present and future - comes from whakapapa links - to the past through ancestors, to the present through family, and to the future through children and grandchildren. Whakapapa is not only about personal identity, but also connects to the whānau ('family') and immediate family grouping, as well as the hapu ('sub-tribe') and iwi ('tribe'), who share a common genealogy. Through these connections, whakapapa establishes personal, collective and whänau identities, positioning and connectedness (Berryman, 2008). Whakapapa informs relationships and provides the foundation for inherent connectedness and interdependence to all things (Cheung, 2008). Whitt et al. (2003) add that the importance of whakapapa within Māori culture cannot be overestimated. Whakapapa is a way of thinking which is fundamental to almost every facet of a Māori world view: 'Whakapapa is a way of thinking, a way of learning, a way of storing knowledge, and a way of debating knowledge. It is inscribed in virtually every aspect of our worldview' and acts as a 'fundamental form of knowing: it functions as an epistemological template' (Smith, 2000: 234).

\section{Tikanga}

The ways in which Māori conduct their lives are encapsulated in the concept of tikanga. Tikanga comes from the word tika and means the nature or function of a thing (Patterson, 1992). Mead (2003) describes tikanga as a rule, method or habit. Tikanga relates to things such as actions, habits, appearance and customs, including how and why people behave in certain ways. Mead (2003) relates tikanga Māori to 'the Māori way' or in accordance with Māori customs. The important quality is 'being in accord with human nature, or rather, being in accord with tribal nature, being 
"natural" and hence being reasonable and correct' (Patterson, 1992: 103). This requires one to be in accord with and follow customs and common practices laid down by tribal ancestors, and thus to be a full human being. Tikanga therefore provides a reference point for behaviours, customs and practices from the past, laid down by ancestors for future generations. It emphasises how the past shapes both present and future identities, relationships and behaviours. Tikanga offers models, inspiration and guides for how to live our lives, and can be utilised to reconceptualise early childhood education provision in Aotearoa New Zealand. In the following section, I discuss aspects of tikanga that can support reconceptualising early childhood education provision, including karakia ('prayers', 'incantations'), pepeha ('introductions'), pūrākau ('narratives') and whakataukī ('proverbs').

\section{Karakia ('prayers', 'incantations')}

The term karakia has a number of meanings, including 'prayers', 'incantations', 'offertories', 'recitations', 'ritual words', 'rites', 'pleas' and 'invocations' (Rewi, 2012). They are the chants of Māori ritual, utilising traditional language, constructs and symbols. Karakia allow one to become one with the atua ('gods'), the ancestors, history and the past. They are a means of communicating with the gods and connecting with the spiritual realm and the universe in its entirety (Shirres, 1997). Karakia enable one to carry out one's daily activities in accord with the ancestors and the spiritual powers. Karakia act as an intermediary, affirming the relationship between the spiritual and the temporal worlds (Rewi, 2012).

As discussed previously, wairua denotes 'two waters' - the physical and the spiritual. It is important that balance or harmony be maintained between these two waters, and karakia are a means of achieving this. Pere (1991: 16) explains that: 'Everything has a wairua, for example, water can give or take life. It is a matter of keeping balance'. Maintaining balance or harmony is a key feature of Māori understandings and practices - balance between the sacred and the secular, good and bad, life and death. The Māori view of the world is one where balance is maintained across different forces. The following is an example of an ancient karakia passed down through the generations to acknowledge the forces of the environment and support harmony and balance:

Whakataka te hau ki te uru, Whakataka te hau ki te tonga.

Kia mākinakina ki uta, Kia mātaratara ki tai.

E hì ake ana te atākura he tio, he huka, he hauhunga.

Haumi e! Hui e! Tãiki e!

Get ready for the westerly and be prepared for the southerly.

It will be icy cold inland, and icy cold on the shore.

May the dawn rise red-tipped on ice, on snow, on frost.

Join! Gather! Intertwine!

The first section of the karakia acknowledges the environmental forces that connect Māori to the gods, the spiritual powers. The second line relates to a relaxing of the more negative aspects of those forces and the strengthening of the beneficial ones. The third line involves naming what is needed for oneness with the gods, and the final line adds strength to that oneness. The karakia is therefore not only a communication with the gods, but also works to balance the forces of the environment to achieve a harmonious world. 
It must be acknowledged that the recitation of karakia is part of everyday practice in a growing number of early childhood services in Aotearoa New Zealand, mostly at the beginning and end of the day and before meals. For some, this is done primarily as a means of meeting the expectations of the bilingual/bicultural early childhood curriculum document Te Whāriki: He Whāriki Matauranga mo ngā Mokopuna o Aotearoa/Early Childhood Curriculum (Ministry of Education, 1996). Te Whāriki includes statements about the importance of recognising the significance of whakapapa; recognising and acknowledging the spiritual dimensions of the world and the child; being aware of how the past, present and future influence the child; respecting the natural environment; and recognising Māori ways of knowing and making sense of the world. While acknowledging that there has been movement in integrating these expectations into early childhood programmes, there remains little understanding of how these aspects of Māori culture can be recognised, acknowledged and valued. For example, rather than being a means of communicating with the gods, the spirit world and the ancestors, and a powerful connecting force to the past, the environment and the Māori world, karakia can be lost in the mundane and the routine, being the step after 'hand-washing' and before 'story time'. In order to develop stronger, more respectful relationships with and connections to the Māori world, the place of karakia must be repositioned in early childhood theory and practice through the development of understandings and acknowledgement of the intent, meaning, purposes and power of karakia. Initial teacher education has an important role to play in achieving this goal.

\section{Pepeha ('introductions')}

Pepeha are another means of developing deeper understandings of and connectedness to the Māori world - past, present and future. A pepeha is a way of introducing oneself to others. It is based on whakapapa and tells one's story, one's affiliations to people, places and events, one's relationships to the environment and one's connectedness to the spiritual realm. It addresses questions that are critical to identity as Māori and what it means to be Māori: 'Ko wai koe? Nā wai koe? I ahu mai koe i hea? Who are you? From whom are you? Where have you come from?' (Ministry of Education, 2009: 50). Durie explains that:

As whakapapa is told and retold, the interconnections between the living and the ancestors, the deities and the land become clear. From the personification of the pantheon down through the eponymous ancestors, the shaping of the individual and the collective Māori identity is set within the context of the personal, the collective and the total environment. (Durie, 1997: 146)

The following is the author's pepeha:

Ko Tararua te maunga

Ko Ohau te awa

Ko Tainui te waka

Ko Ngāti Tukorehe te hapū

Ko Ngāti Raukawa te iwi

Ko Karanama Ruihi raua ko

Hineheru Te Hiwi oku tipuna

Ko Les Wyllie raua ko Parewai

Ruihi oku matua

Ko Lesley Rameka toku ingoa
My ancestral mountain is Tararua

My ancestral river is Ohau

Tainui is my ancestral canoe

Ngāti Tukorehe is my sub-tribe

Ngāti Raukawa is my tribe

Karanama Ruihi and Hineheru

Te Hiwi are my grandparents

Les Wyllie and Parewai Ruihi

are my parents

Lesley Rameka is my name 
The pepeha answers the questions posed above. 'Who are you?': I am the daughter of Parewai and Les, and the granddaughter of Karanama and Hineheru. 'From whom are you?': I am a descendent of Tukorehe and Raukawa, great chiefs of the past, and so am related to other members of my tribe and sub-tribe. 'Where have you come from?': My people came to Aotearoa New Zealand from Hawaiki (our spiritual homeland) on the Tainui canoe, and our ancestral lands are beside the Tararua mountain range and the Ohau River. Through reciting my pepeha and whakapapa, I connect myself to my people - past, present and future - to my primeval parents, to the land, the lakes, the rivers and the mountains, to my tribal history, to the spiritual world, to the universe and to my audience.

Knowledge of one's pepeha and the ability to recite it is therefore not only critical to connections with the environment, with the spiritual and physical worlds, with people - past, present and future - and with the creation of the world, but is also central to the development of a strong sense of identity and belonging as Māori. Early childhood education has an important role in supporting young children's sense of identity and belonging as Māori, and knowing the child is key to this. From a Māori perspective, knowing the child requires not only knowing the child as an individual, but also knowing the child as Māori, communally, historically and culturally. This requires knowing the child's connections to people and places - past, present and future - to whakapapa, and to iwi, hapū and whānau (Berryman, 2008; Cheung, 2008; Pere, 1991; Rangihau, 1977; Reedy, 1979). This is not achievable when early childhood teachers lack cultural knowledge and understandings (Mahuika et al., 2011; Mara and Marsters, 2009). Ritchie (2003: 10) notes the 'extent to which a largely Pākeha [New Zealander of British descent] early childhood teaching force are able to deliver on expectations that require a level of expertise that is beyond their experience as monocultural speakers of English with little experience of Māori culture and values'. For early childhood teachers, gaining understandings of children's connectedness to people and the Māori world is key not only to knowing the child, but also to knowing the child as Māori. Whānau ('families') are the custodians of this knowledge, and willingness to share it is often dependent on relationships with teachers and the service, and trust that the information being shared will be respected, valued and protected. The challenges for teachers, therefore, are, firstly, to develop understandings not only about pepeha and whakapapa, but also about how they can be expressed in practice, in a meaningful and authentic way, and, secondly, to explore how, with the support and guidance of whānau and community, service practices, such as mihimihi (the recitation of pepeha), can be instigated.

A further aspect of knowing and connecting to the past, as pointed out by Patterson (1992), is recognition that knowing about one's ancestors is not only about reciting one's whakapapa. It is also important to know what they did, what they valued, how they viewed their world, and how they behaved. Püräkau ('narratives') are critical in this regard.

\section{Pūrākau ('narratives')}

Pūrākau is a term that is often used to refer to Māori and tribal narratives, myths and legends (Lee, 2009). The telling and retelling of stories has always been critical to retaining knowledge from the past and transmitting it down through the generations (Lee, 2009; Rameka, 2011). Traditional Māori narratives are rhetorical in that the telling is a means of preserving moral and historical messages and values. They are part of Māori symbolism, culture and world views, and include philosophical understandings and thinking, cultural norms, and behaviours fundamental to Māori views of self and identity.

Walker (1978) maintains that mythology can be likened to a mirror image of culture, reflecting the philosophy, norms and behavioural aspirations of people. Myths can function in two ways: firstly, as an outward projection of an ideal by which one can measure and perfect performance, 
and, secondly, as a reflection of current social norms, prescriptions and behaviours, which is more about instruction and validation. Perceptions of reality, including what is viewed as real, probable and possible, relate to ideas of what reality is, including the way the world is structured, ways of knowing and being, and traditional experiences (Wearmouth et al., 2005). These views of reality permeate cultural narratives and logic, and are the basis of world views. 'Patterns of life that extend from the past are inherent in discourse and metaphor, in logic and narrative. Communications such as these provide evidence to interpret the understandings and intention of a particular group of people' (Berryman, 2008: 40).

Although the characters of myth possess supernatural powers and live in a world of gods, they display many human-type feelings, such as love, hate, jealousy, and anger, and therefore can provide humans with heroic characters and behavioural characteristics (Walker, 1978). According to Marsden (2003), traditional Māori myths and legends were deliberate constructs used by ancestors to encapsulate and condense their world views, their ideas about reality and their relationship between the spirit world, the universe and man in easily assimilable forms. They provided culturally authentic precedents for behaviour, including morals, values, ethics and formative elements that were central to the culture and guided ways of being and interacting within the world (Patterson, 1992).

Traditional Māori stories are therefore part of the cultural symbolism that forms the foundation of a Māori worldview, a view of the world that is also maintained in many traditional cultural practices and that still forms an important part of Māori society today. These traditional understandings ... contribute to how we perceive our identity as Māori in contemporary New Zealand society today. (Berryman, 2008: 41)

The stories of Māui-tikitiki-a-Taranga are an example of how cultural world views, knowledge and values are handed down from generation to generation. Māui-tikitiki-a-Taranga had godly origins but also carried the seeds of humanity - he was a physical as well as a spiritual being (Keelan, 2006; Rameka, 2011). He was the ancestor hero, known throughout Polynesia. A quick scan of the names he is known by gives one an insight into his character: Māui-potiki ('youngest child'), Māui-tikitiki-a-Taranga (association with 'head', 'sacred'), Māui-nukurau ('trickster'), Māuimohio ('great knowledge'), Māui-atamai ('quick-witted'), Māui-toa ('brave') and Māui-tinihanga ('of many devices'). His traits include intelligence, initiative, boldness, persistence and determination, as well as characteristics such as laziness, deviousness, recklessness and mischievousness (Walker, 1996). Māui served as a model, characterising the personal qualities and traits valued in Māori society: 'He was quick, intelligent, bold, resourceful, cunning and fearless, epitomising the basic personality structures idealised by Māori society' (Walker, 1990: 15). The Māui narratives therefore serve as an illustration of culture, reflecting the philosophy, norms and behavioural aspirations of the people, highlighting social practice, and presenting a model for people to aspire to.

What is clear from exploring the Māui narratives is that some of the morals, themes, models and behaviours central to being Māori, which guide Māori ways of being and interacting within the world (Rameka, 2011, 2012), do not necessarily align with western (teacher-training) perspectives of appropriate behaviours and ways of being in the world. Concepts such as whakatoi, which can be translated as 'cheekiness', 'annoying' or 'teasing', do not tend to fit with mainstream early childhood expectations of behaviour, but make sense in the context of the indulged, precocious, high-spirited Māori child. An even harder concept to reconcile in early childhood is tinihanga or 'cunningness', 'deception' and 'trickery', which are recurring themes throughout Māori narratives. Pūrākau can provide pathways from the past into future early childhood education. However, it requires acknowledgement of the values that are integral to the pürākau and a change in the ways that concepts such as tinihanga and whakatoi are viewed. 
In this way, the past can shape both present and future identities, relationships and behaviours. The challenge for early childhood teachers is to be open to expectations, values and models of behaviour that may differ and in some cases clash with their own. It is about recognising that culture shapes the way we think and interpret information, and impacts markedly on teaching and learning. Delpit (1995: 151) argues that: 'We all interpret behaviours, information, and situations through our own cultural lenses; these lenses operate involuntarily, below the level of conscious awareness, making it seem that our own view is simply "the way it is". The challenge for teachers, therefore, is to critically reflect on the lenses they utilise, and work towards new lenses and ways of seeing the world, teaching and children.

\section{Whakataukī ('proverbs')}

Whakatauki are another means of handing down ancient wisdom and knowledge through the generations to guide people's lives, and treasures from the past to support our aspirations for today and the future. Patterson (1992) points out that the ethical importance of the past is evident in the authority accorded to the words and deeds of the ancestors, and these feature strongly in a range of whakatauki. Whakatauki were viewed as metaphors for human behaviours and often spoke of connections between people or the environment and the elements within it, such as birds, rivers and mountains. Within whakatauki were messages about valued characteristics, personal virtues, modes of behaviour, life lessons and appropriate courses of action (Hemara, 2000; Patterson, 1992). For example, the well-known whakatauki E kore au e ngaro, he kākano i ruiruia mai $i$ Rangiātea ('I will never be lost; the seed was sown in Rangiātea') emphasises that the speaker knows his or her whakapapa ('genealogy') to Rangiātea (the Māori spiritual homeland), so is confident and secure with a positive future. Not only does the whakatauki stress the importance of a secure Māori identity to the well-being of the individual, but it also highlights an interpretive system that frames Māori world views, including the spiritual origins and direct connections to the gods (Berryman, 2008). Reedy relates the whakatauki to the importance of the young child in Māori society, stating:

Māori tradition identified the Māori child as a valued member of the Māori worlds - before conception, before birth, before time. The child was the personification of the worlds of yesterday: he purapura i ruia mai i Rangiatea, e kore e ngaro. Precious seeds dispersed from Rangiatea (the famed homeland of the Māori gods) will never be lost. As precious seeds, the child was nurtured for survival and inculcated with an understanding of their own importance. (Reedy, 2003: 55)

Whakatauki such as Kia mau koe ki te kupu a tou matua ('Hold fast to the words of your parent or ancestors') (Patterson, 1992: 65) stress the importance of the words and messages of ancestors for successive generations. Ancestors' words were viewed as having authority, and therefore true and reliable. A similar message is found in E kore e hekeheke, he kakano rangatira ('I am not declining [like the sun], I am of chiefly stock') (Patterson, 1992: 66) to emphasise the relationship between young children and rangatira 'noblemen' or 'chiefs'. The term rangatira encapsulates many Māori virtues, aspirations and human possibilities, including ideas of beauty, strength and courage (Patterson, 1992). Another, Kia u, kia mau ki to Māoritanga ('Cleave to and retain the very essence of being Māori'), stresses the importance of holding onto one's sense of being Māori (Karetu, 1992: 38), as does Puritia ngā taonga a ngā tūpuna mō ngā puāwai o te ora, à mātou tamariki ('Hold fast to the cultural treasures of our ancestors for the future benefit of our children') (Ministry of Education, 2009: 51). These whakatauki are linked to identity and are akin to communicating with ancestors. 


\section{Ehara taku toa $i$ te toa takitahi engari he toa takitini.}

I come not with my own strengths but bring with me the gifts, talents and strengths of my family, tribe and ancestors.

This whakatauki emphasises the importance of young children knowing themselves, their essence of being, and taking strength from their family, tribe and ancestors. Māori children are perceived both in terms of he taura here tangata, 'the binding rope that ties people together over time', and te kâwai tangata, the 'genealogical link' that enhances family relationships (Metge, 1995; Reedy, 1991, 2003). The child is a living connection to the family - past, present and future - a living embodiment of ancestors, and a link in descent lines stretching from the beginning of time into the future (Metge, 1995; Reedy, 1991, 2003). In terms of early childhood practice, whakatauki provide a door to the Māori world. They contain the wisdom, knowledge and values passed down through the generations, and so can contribute meaningfully to teaching and learning in early childhood. Reflections on what messages can be derived from whakatauki and how they can be authentically integrated into an early childhood programme are essential.

\section{Conclusion}

In conclusion, the opening whakatauki - Kia whakatomuri te haere whakamua ('I walk backwards into the future with my eyes fixed on my past') - expresses the Māori perspective of time, where the past, present and future are intertwined, and life is a continuous cosmic process. It highlights Māori ways of viewing the world and being within the world. Furthermore, it frames Māori views of time, where one travels backwards into the future and where ancestors live with their descendants in the physical as well as spiritual world.

Early childhood has an important role to play in the lives of young children. While teachers want the best for children, achieving this is a complex process. One of the reasons for this, according to Bevan-Brown (2003), is that teachers are often unaware of the importance of children's culture and world views in making meaning of learning and, therefore, do not know how to address these issues within their teaching practice. In Aotearoa New Zealand, early childhood teachers have a responsibility to provide a setting where Māori perspectives of the world are embraced. They have a responsibility to ensure that Māori children have access to environments, materials and learning activities that support pride in and connectedness to the continuum of life, from the spiritual world to the physical world. Teachers' pedagogy and practice must also acknowledge and reflect the child's spiritual being and the spiritual connections they bring to the setting, including to ancestors who have passed on but are always present in the environment - their whakapapa connections to the creation of the world and the world of the gods, to people, to places and to other entities in the living environment.

While 'time' as a cultural concept has not been specifically referenced in this article, it has explored notions of past, present and future as a continuum, where time is transient and experienced in relation to cultural concepts and knowledge. The whakatauki discussed in this article refer to concepts about the importance of acknowledging the environmental forces that connect Māori to the gods, the spiritual powers and the spiritual world; recognising and being grounded within the Māori world view, culture and history; and the importance of young children knowing themselves, their essence of being, and taking strength from their family, tribe and ancestors. All of the concepts relate to Māori experiences of time. Through engaging and connecting with these cultural concepts, Māori perspectives of the past can provide guides for early childhood education 
provision. In summing up, the past is central to and shapes the present and the future. Māori perspectives of the past can provide models, inspiration and guides to reconceptualise early childhood education provision in Aotearoa New Zealand if they are approached with honesty, humility and a genuine desire to make a difference.

While acknowledging that there has been movement in integrating these expectations into early childhood programmes, there remain many challenges to the meaningful integration of Māori ways of knowing in teaching and learning. The principle challenge for teachers is to gain deeper understandings of the Māori world. This requires that teachers critically reflect on their own cultural lenses, which often operate involuntarily, below the level of consciousness. This makes it seem that one's view is normal, natural and just 'the way it is', resulting in little consideration being given to the ways culture reinforces values, beliefs and teaching. Critical reflection allows teachers to be open to different ways of seeing the world, teaching and children, to understand the child and the child's world. A further challenge relates to accessing knowledge and understandings that support new ways of seeing and knowing. This requires that teachers make a commitment to researching the Māori world in order to gain better understandings and ways to implement those understandings. Karakia, pūrākau and whakatauki may provide an entry to the Māori world. However, how they can be integrated into an early childhood programme can be problematic. For example, connecting to the spiritual realm is not simply a matter of performing a karakia before eating, or retelling a püräkau during story time. Neither is it about asking children to recite their pepeha during mat time. Rather it is about authenticity and integrity. It requires authentically enacted practices that are real, meaningful and integral to the operation of the early childhood service.

\section{Funding}

The author(s) received no financial support for the research, authorship, and/or publication of this article.

\section{References}

Barlow C (1991) Tikanga Whakaaro: Key Concepts in Māori Culture. Auckland, New Zealand: Oxford University Press.

Berryman M (2008) Repositioning within indigenous discourses of transformation and self-determination. PhD Thesis, University of Waikato, Hamilton, New Zealand.

Bevan-Brown J (2003) The Cultural Self-Review: Providing Culturally Effective, Inclusive Education for Māori Learners. Wellington, New Zealand: NZCER Press.

Cheung M (2008) The reductionist-holistic worldview dilemma. MAI Review 3: Research Note 5. Available at: http://www.review.mai.ac.nz/index.php/MR/article/viewFile/186/196

Delpit L (1995) Other People's Children: Cultural Conflict in the Classroom. New York: New Press.

Durie A (1997) Te aka matua: Keeping a Māori identity. In: Te Whaaiti P, McCarthy M and Durie A (eds) Mai i Rangiatea: Māori Wellbeing and Development. Auckland, New Zealand: Auckland University Press with Bridget Williams Books, pp. 142-162.

Hemara W (2000) Mãori Pedagogies: A View from the Literature. Wellington, New Zealand: New Zealand Council for Educational Research.

Karetu T (1992) Language and protocol of the Marae. In: King M (ed.) Te Ao Hurihuri: Aspects of Māoritanga. Auckland, New Zealand: Reed Books, pp. 29-42.

Keelan T (2006) Case study: GYME. In: New Zealand Educational Administration and Leadership Society biennial international conference, Nelson, New Zealand, 18-21 April 2006.

Lee J (2009) Decolonising Māori narratives: Pūrākau as a method. MAI Review 2: Article 3. Available at: http://ojs.review.mai.ac.nz/index.php/MR/article/viewFile/242/268

Love C (2004) Extensions on Te Wheke. Wellington, New Zealand: Open Polytechnic of New Zealand. 
Mahuika R, Berryman M and Bishop R (2011) Issues of culture and assessment in New Zealand. Assessment Matters 3: 183-198.

Mara D and Marsters M (2009) Pasifika students: Supporting academic success through the provision of mentoring. Report to Ako Aotearoa: Regional Hub, Eastern Institute of Technology, Hawkes Bay, New Zealand.

Marsden M (2003) The Woven Universe: Selected Writings of Rev. Māori Marsden. Masterton, New Zealand: Estate of Rev. Māori Marsden.

Mead H (2003) Tikanga Māori: Living by Māori Values. Wellington, New Zealand: Huia Ministry of Education. Metge J (1995) New Growth from Old: The Whänau in the Modern World. Wellington, New Zealand: Victoria University Press.

Ministry of Education (1996) Te Whāriki: He whāriki Mātauranga mō ngā Mokopuna o Aotearoa/Early Childhood Curriculum. Wellington, New Zealand: Learning Media.

Ministry of Education (2009) Te Whatu Pōkeka: Kaupapa Māori Assessment for Learning: Early Childhood Exemplars. Wellington, New Zealand: Learning Media.

Ministry of Justice (2001) He hinātore ki te ao Māori: A glimpse into the Māori world. Māori perspectives on justice. Wellington, New Zealand: Ministry of Justice.

Patterson J (1992) Exploring Māori Values. Palmerston North, New Zealand: Dunmore Press.

Pere R (1991) Te Wheke: A Celebration of Infinite Wisdom. Gisborne, New Zealand: Ao Ako Global Learning.

Rameka L (2011) Māui-tikitiki-a-tarangā: Culturally relevant assessment. In: Whitinui P (ed.) Ka Tangi te Titi. Wellington, New Zealand: NZCER Press, pp. 104-121.

Rameka L (2012) Te whatu kakahu: Assessment in Kaupapa Māori early childhood practice. PhD Thesis, University of Waikato, Hamilton, New Zealand.

Rangihau J (1977) Being Māori. In: King M (ed.) Te Ao Hurihuri: The World Moves On: Aspects of Māoritanga. Wellington, New Zealand: Hicks Smith, pp. 165-176.

Reedy T (1979) He Mãtāpuna. Wellington, New Zealand: New Zealand Planning Council.

Reedy T (1991) A Tangata Whenua Perspective of Early Childhood. Paper presented at the fourth Australia and New Zealand, 'The First Years of School' Conference, College of Education, Auckland, New Zealand.

Reedy T (2003) Toku rangitiratanga na te mana-matauranga: 'Knowledge and power set me free...' In: Nuttall J (ed.) Weaving Te Whäriki. Wellington, New Zealand: NZCER Press, pp. 51-77.

Reilly P ( 2004) Te timatanga mai o nga atua: Creation narratives. In: Ka'ai TM, Moorfield JC, Reilly MPJ, et al. (eds) Ki Te Whaiao: An Introduction to Mãori Culture and Society. Auckland, New Zealand: Pearson Education, pp. 1-12.

Rewi P (2012) Karakia Mäori: Mäori invocations to spiritual authorities. He Pukenga Korero 9(2): 15-20.

Ritchie J (2003) Whakawhanaungatanga: Dilemmas for mainstream New Zealand early childhood education of a commitment to bicultural pedagogy. In: Proceedings of the 11th reconceptualizing early childhood education conference, Tempe, AZ, January 2003. Available at: http://unitec.researchbank.ac.nz/ bitstream/handle/10652/1479/Ritchie\%20-\%20Whakawhanaungatanga.pdf?sequence=1\&isAllowed=y

Shirres M (1997) Te Tangata: The Human Person. Auckland, New Zealand: Accent.

Smith L (2000) Kaupapa Māori research. In: Battiste M (ed.) Reclaiming Indigenous Voice and Vision. Vancouver, BC, Canada: University of British Columbia Press, pp. 225-247.

Te Rito S (2007) Whakapapa: A Framework for Understanding Identity. MAI Review, 2, Article 2, 10 pages. Available at: http://www.review.mai.ac.nz

Tse S, Lloyd C, Petchkovsky L, et al. (2005) Exploration of Australian and New Zealand indigenous people's spirituality and mental health. Australian Occupational Therapy Journal 52(3): 181-187.

Walker R (1978) The relevance of Māori myth and tradition. In: King M (ed.) Tihei mauri ora. Auckland: Methven.

Walker R (1990) Ka Whawhai Tonu Matou: Struggle without End. Auckland, New Zealand: Penguin.

Walker R (1993) A paradigm of the Māori view of reality In: David Nichol seminar IX, Voyages and beaches: Discovery and the Pacific 1700-1840, Auckland, New Zealand, 24 August 1993.

Walker R (1996) Ngā Pepa a Ranginui: The Walker Papers. Auckland, New Zealand: Penguin. 
Wearmouth J, Glynn T and Berryman M (2005) Perspectives on Student Behaviours in Schools: Exploring Theory and Developing Practice. Abingdon: Routledge.

Whitt L, Roberts M, Norman M, et al. (2003) Indigenous perspectives. In: Jamieson D (ed.) A Companion to Environmental Philosophy. Malden, MA: Blackwell, pp. 3-20.

Wolfgramm R and Waetford C (2009) Spiritual efficacy and transcendental phenomenology: Accessing the contemplative from a Māori perspective. In: 6th international critical management studies conference, University of Warwick, 13-15 July 2009.

\section{Author biography}

Lesley Rameka is a senior lecturer at the Faculty of Education, University of Waikato in Tauranga, where she teaches in the early childhood and Māori education programmes. Lesley has worked in early childhood education for over 30 years, beginning her journey in te kohanga reo, and working in a number of professional development and tertiary education providers over the years. Lesley's research interests include: Māori early childhood education, Kaupapa Māori Assessment in early childhood, curriculum development in Māori early childhood services and Māori pedagogies. Lesley's current interests are centred on reclaiming Māori and Pacific perspectives of Infants and Toddlers care and education and reframing them for contemporary in early childhood contexts. 